\title{
OSL dating of Weichselian ice-free periods at Skorgenes, western Norway
}

\author{
Johanna Anjar ${ }^{1,2}$, Helena Alexanderson ${ }^{3}$, Eiliv Larsen ${ }^{4} \&$ Astrid Lyså ${ }^{4}$ \\ ${ }^{1}$ National Laboratory for Age Determination, NTNU University Museum, Sem Selands vei 5, 7491 Trondheim, Norway. \\ ${ }^{2}$ Present address: University of South-Eastern Norway, Gullbringvegen 36, 3800 Bø, Norway. \\ ${ }^{3}$ Department of Geology, Lund University, Sölvegatan 12, 22362 Lund, Sweden. \\ ${ }^{4}$ Geological Survey of Norway, P.O. Box 6315 Torgarden, 7491 Trondheim, Norway. \\ E-mail corresponding author (Johanna Anjar): johanna.anjar@gmail.com
}

\begin{abstract}
During recent years, many sites with sediments pre-dating the Last Glacial Maximum have been identified in formerly glaciated areas. As more and better dates are presented from these sites, the dynamic behaviour of the Scandinavian Ice Sheet is becoming increasingly clear. In this study, we revisited the site Skorgenes in western Norway. Here, sediments from two ice-free periods are found below and interbedded with glacial diamicts. We present an updated chronology for the site, based on ten new Optically Stimulated Luminescence (OSL) dates, and discuss possible correlations. The samples had poor OSL properties but still provide a substantial improvement of the existing chronology. The oldest sediments identified at Skorgenes were deposited in a proglacial subaqueous setting at some point between 21 and $42 \mathrm{ka}$. This period was followed by a glacial advance and, during the subsequent ice retreat, a delta or subaqueous fan formed at Skorgenes. OSL ages from the foreset beds indicate deposition at some point between 17 and $30 \mathrm{ka}$, implying that the ice-front retreated east of Skorgenes at least once during the Late Weichselian. A substantial ice advance followed this retreat. The youngest sediments, forming a proglacial delta succession, were deposited during the final deglaciation of the site.
\end{abstract}

Keywords: Optically Stimulated Luminescence, Interstadial, Marine Isotope Stage 2, Stratigraphy, Scandinavian Ice Sheet, Western Norway

Electronic Supplement 1: Table with additional analytical information for the OSL samples.

Electronic Supplement 2: Figure showing dose distributions for the four samples deemed acceptable.

Received 3. November 2017 / Accepted 14. May 2018 / Published online 23. August 2018

\section{Introduction}

The Scandinavian Ice Sheet has had a complex Weichselian history. Periods with extensive ice coverage were interrupted by periods of substantial ice retreat as indicated by interstadial sediments found also in the central parts of the formerly glaciated area (e.g., Helmens et al., 2009; Alexanderson et al., 2010; Hättestrand \& Robertsson, 2010; Wohlfarth et al., 2011; Möller et al., 2013). In western Norway, studies of the Skjonghelleren and Hamnsundhelleren coastal caves provide a welldated record of some of these glacial advances and retreats (Larsen et al., 1987; Valen et al., 1996). Here, the ice advanced out onto the shelf at $41 \mathrm{cal}$. ka BP and again after $34.5 \mathrm{cal}$. ka BP, interrupted by an ice retreat during the Ålesund interstadial at 34.5-38.2 cal. ka BP, post-dating the Laschamp event (Mangerud et al., 2010). The Last Glacial Maximum (LGM) extent was reached at around $27 \mathrm{ka}$ in this region (e.g., Hughes et al., 2016; Larsen et al., 2016). The glacial fluctuations at the outer coast are thus reasonably well constrained, but less is known about the spatial extent of the ice sheet farther inland. At Skorgenes, $50 \mathrm{~km}$ east of Skjonghelleren, a regionally unique stratigraphy with sediments from two pre-LGM ice-free periods has been identified beneath a marine-limit delta (Larsen \& Ward, 1992; Larsen et al., 1995). Together with the site's easterly position, the stratigraphy could make it a key site for reconstructions

Anjar, J., Alexanderson, H., Larsen, E. \& Lyså, A. 2018: OSL dating of Weichselian ice-free periods at Skorgenes, western Norway. Norwegian Journal of Geology 98, 301-313. https://dx.doi.org/10.17850/njg98-3-02. 
of the glacial history. Unfortunately, an earlier attempt to date the sediments was largely unsuccessful (Larsen \& Ward, 1992). The site's stratigraphic importance and the significant advances in optically stimulated luminescence (OSL) dating during the last 25 years have therefore motivated a new attempt to constrain the timing of sediment deposition at this site. Here, we present an updated chronology for Skorgenes based on ten new OSL ages and discuss ways to overcome the remaining uncertainties. The description of the sediment succession largely follows Larsen \& Ward (1992) but new observations have been added.

\section{Study area}

Skorgenes is situated at the intersection between the E-W-trending Skorgedalen valley and the N-S-trending fjord Tresfjorden, which is a tributary to Moldefjorden $\left(62^{\circ} 34^{\prime} 11.7^{\prime \prime} \mathrm{N}, 7^{\circ} 06^{\prime} 14.0^{\prime \prime} \mathrm{E} ;\right.$ Fig. 1). Regionally, the landscape is dominated by large E-W-trending fjords. At Skorgenes, a narrow valley has been filled with several generations of ice-proximal sediments. Fluvial erosion has subsequently cut into the sediments, exposing the stratigraphy on both sides of the valley. Three

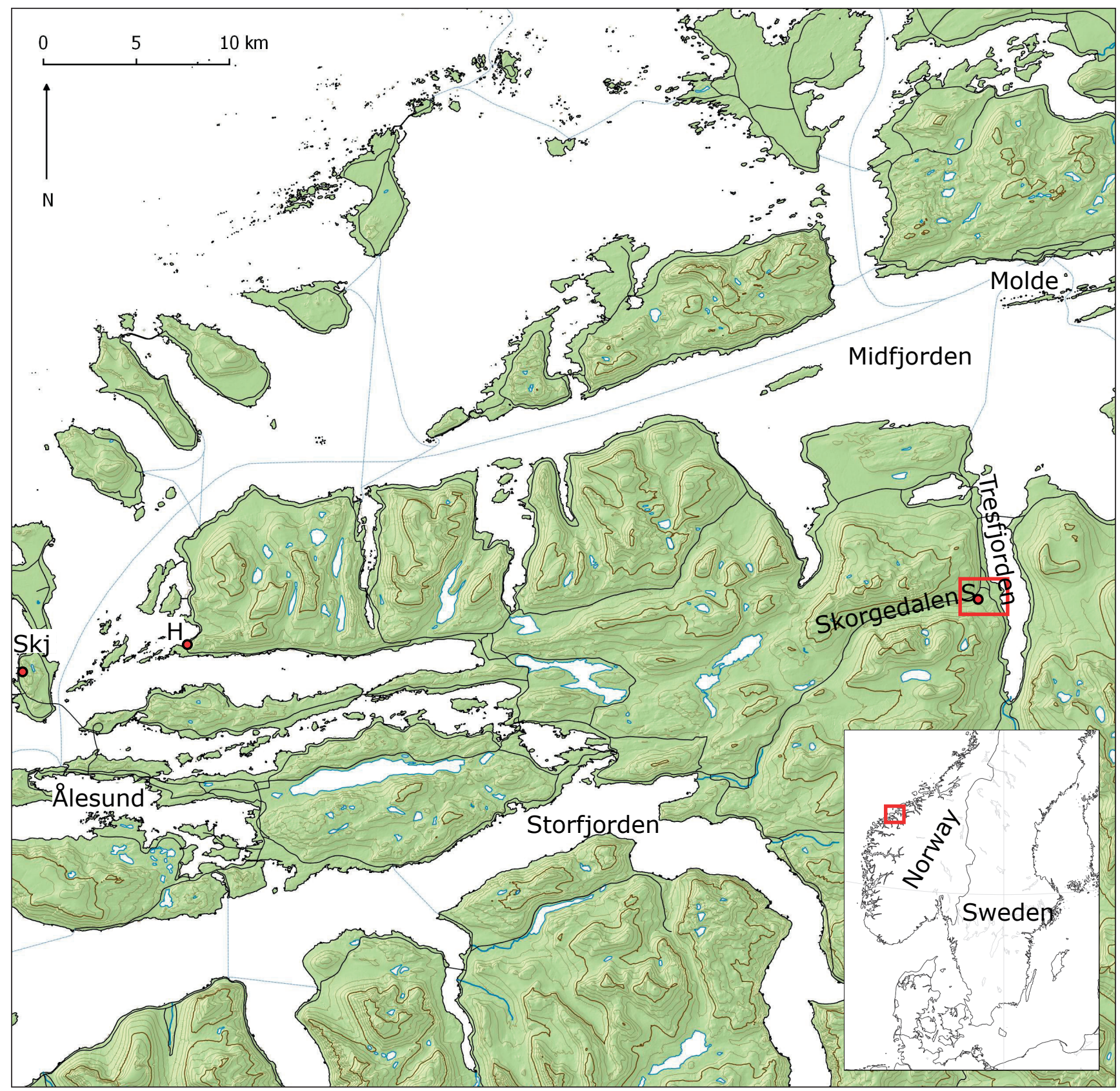

Figure 1. Overview map over the study area. $S=$ Skorgenes, $S k j=$ Skjonghelleren cave, $H=$ Hamnsundhelleren cave. Altitude is shown with $100 \mathrm{~m}$ contours. The extent of Fig. $2 \mathrm{~B}$ is indicated by the red rectangle. 
sedimentary terrace levels are visible above the presentday sea level, the Tapes terrace at $\sim 20 \mathrm{~m}$, the Younger Dryas terrace at $\sim 60 \mathrm{~m}$ and the marine limit (ML) at $\sim 90$ $\mathrm{m}$ (Fig. 2). The investigated sections are all situated in a sediment sequence underlying the ML terrace.

\section{Methods}

Twelve samples were taken for OSL dating and dated at Lund University Luminescence Laboratory (Table 1, Electronic Supplement 1). The samples were taken in opaque plastic tubes which were hammered into freshly cleaned vertical sediment surfaces. The stratigraphic position of each sample was identified based on the sedimentological descriptions made by Larsen \& Ward (1992) whose stratigraphic units were readily identifiable in the section. To get a homogeneous background radiation (dose rate) for the OSL samples, lithological boundaries were avoided when possible but the heterogeneous nature of units 4 and 7 meant that in these units the distance to layer boundaries was generally less than $30 \mathrm{~cm}$. However, since the material in all these beds is expected to be derived from the same source, the variation in dose rate between beds is assumed to be small, which was confirmed by comparing the dose rates of the measured samples (Table 1). For all samples the 180-250 $\mu \mathrm{m}$ fraction was selected for analysis as a relatively coarse fraction is often better bleached than finer fractions in glacifluvial settings (Truelsen \& Wallinga, 2003; Alexanderson, 2007). The preparation included treatment with $10 \% \mathrm{HCl}$ to remove carbonates, $10 \% \mathrm{H}_{2} \mathrm{O}_{2}$ to remove any organic material and density separation at $2.62 \mathrm{~g} / \mathrm{cm}^{3}$ (LST Fastfloat). The quartz separate was then treated with $38 \% \mathrm{HF}$ to remove remaining impurities and to etch the outer surfaces of the grains, and finally with $10 \% \mathrm{HCl}$ to clean out any fluorides.

The single aliquot regeneration (SAR) analytical protocols (Murray \& Wintle, 2000, 2003) were adapted to account for the individual properties of each sample, particularly the amount of apparent feldspar contamination. Six samples showed significant feldspar contamination and were therefore measured with a post-IR blue protocol, while the rest, which showed no or variable feldspar contamination, have been measured with blue stimulation followed by an infrared check (cf., Duller, 2003) to be able to identify any problematic aliquots. The luminescence signal from the quartz was fairly dim so large aliquots were required to get enough light for measurement. Although the aliquots were large $(8 \mathrm{~mm})$, the number of grains was kept relatively low; a few hundred compared to around a thousand that is more common for large aliquots. Still, a \pm 20 acceptance threshold had to be

Table 1. OSL and TL ages from Skorgenes. Elevations and burial depths are only estimated. The ages used in the text and figures are indicated in bold. 0: This study; 1: Larsen \& Ward, 1992. Laboratory reference, R: Risø; numbers: Lund. Additional analytical information can be found in the supplementary material (Electronic Supplement 1).

\begin{tabular}{|c|c|c|c|c|c|c|c|c|c|c|c|c|c|}
\hline $\begin{array}{l}\text { Laboratory } \\
\text { reference }\end{array}$ & $\begin{array}{c}\text { Sample } \\
\text { name }\end{array}$ & Section & Unit & $\begin{array}{c}\text { Elevation } \\
(m)\end{array}$ & $\begin{array}{c}\text { Burial } \\
\text { depth } \\
(m)\end{array}$ & $\begin{array}{c}n \\
\text { acc./ } \\
\text { total }\end{array}$ & $\begin{array}{c}\text { Total } \\
\text { dose rate } \\
(m G y / a)\end{array}$ & $\begin{array}{l}D e \\
(G y)\end{array}$ & $\begin{array}{c}\text { TL age } \\
\text { (ka) }\end{array}$ & $\begin{array}{c}\text { OSL age } \\
\text { unused } \\
\quad(k a)\end{array}$ & $\begin{array}{c}\text { OSL age } \\
\text { used } \\
(k a)\end{array}$ & $\begin{array}{l}\text { Quality } \\
\text { estimate }\end{array}$ & Reference \\
\hline 15015 & JA2014-18 & $3 \mathrm{~A}$ & 7 & 84 & 4 & $17 / 75$ & $2.31 \pm 0.09$ & $77.9 \pm 10.2$ & & & $34 \pm 5$ & unreliable & 0 \\
\hline 15014 & JA2014-16 & $3 \mathrm{~A}$ & 7 & 61 & 17 & $4 / 9$ & $2.13 \pm 0.09$ & $36.7 \pm 6.1$ & & $17 \pm 3$ & & not usable & 0 \\
\hline R-913810 & el 90076 & $2 \mathrm{~A}$ & 7 & 86 & 3 & & & & & $73 \pm 10^{* *}$ & $41 \pm 5^{\star \star *}$ & unreliable & 1 \\
\hline 15013 & JA2014-11 & $2 \mathrm{~A}$ & 7 & 82 & 7 & $8 / 12$ & $1.96 \pm 0.08$ & $61.8 \pm 6.5$ & & & $32 \pm 4$ & ok & 0 \\
\hline 15012 & JA2014-10 & $2 \mathrm{~A}$ & 7 & 81 & 8 & $17 / 33$ & $1.99 \pm 0.08$ & $69.5 \pm 8.7$ & & & $35 \pm 5$ & unreliable & 0 \\
\hline 15011 & JA2014-09 & $2 \mathrm{~A}$ & $6 / 7$ & 79 & 10 & - & $2.12 \pm 0.09$ & - & & - & & not usable & 0 \\
\hline R-913809 & el 90075 & $2 \mathrm{~A}$ & 4 & 75 & 14 & & & & $73 \pm 10$ & & $39 \pm 5$ & unreliable & 1 \\
\hline 15010 & JA2014-07 & $2 \mathrm{~A}$ & 4 & 75 & 14 & $22 / 39$ & $1.96 \pm 0.08$ & $57.8 \pm 5.8$ & & $29 \pm 3$ & $23 \pm 3^{*}$ & ok & 0 \\
\hline 15009 & JA2014-06 & $2 \mathrm{~A}$ & 4 & 73 & 16 & $17 / 27$ & $2.23 \pm 0.10$ & $37.6 \pm 2.7$ & & & $17 \pm 1.5$ & unreliable & 0 \\
\hline 15008 & JA2014-05 & $2 \mathrm{~A}$ & 4 & 71 & 18 & $24 / 30$ & $2.05 \pm 0.09$ & $39.7 \pm 2.1$ & & & $19 \pm 1.4$ & unreliable & 0 \\
\hline 15007 & JA2014-04 & $2 \mathrm{~A}$ & 4 & 70 & 19 & $24 / 30$ & $2.10 \pm 0.09$ & $48.6 \pm 5.3$ & & & $23 \pm 3$ & unreliable & 0 \\
\hline R-903801 & el 89020 & $2 \mathrm{~B}$ & 1 & 49 & 38 & & & & $63 \pm 6$ & & & not usable & 1 \\
\hline 15004 & JA2014-12 & $2 \mathrm{~B}$ & 1 & 47 & 40 & $41 / 75$ & $2.10 \pm 0.09$ & $79.4 \pm 5.0$ & & & $38 \pm 3$ & unreliable & 0 \\
\hline 15005 & JA2014-13 & $2 \mathrm{~B}$ & 1 & 47 & 40 & $28 / 42$ & $2.23 \pm 0.09$ & $57.8 \pm 4.7$ & & & $26 \pm 2$ & good & 0 \\
\hline 15006 & JA2014-14 & $2 \mathrm{~B}$ & 1 & 47 & 40 & $21 / 27$ & $2.16 \pm 0.09$ & $76.0 \pm 6.8$ & & & $35 \pm 4$ & ok & 0 \\
\hline R-913808 & el 90052 & $2 \mathrm{~B}$ & 1 & 44 & 43 & & & & $51 \pm 5$ & & $28 \pm 3$ & unreliable & 1 \\
\hline
\end{tabular}

*Thermal transfer of $12 \pm 2$ Gy subtracted

${ }^{* *}$ Regeneration technique

${ }^{* * *}$ Added-dose technique 
used to get a sufficient number of accepted aliquots. The equivalent doses for the 10\% and 20\% acceptance thresholds, respectively, are within error of each other for all samples, but the much increased number of aliquots (by 2-4.6 times) for the 20\% threshold provided better counting statistics. The samples were analysed in a Risø TL/OSL reader model DA-20. The first $1.12 \mathrm{~s}$ of the signal were integrated for the peak and the following $1.12 \mathrm{~s}$ for background. The laboratory beta dose rate was $0.15 \mathrm{~Gy} / \mathrm{s}$. Doses were calculated in the Risø Analyst 4.31 software with exponential curve fitting. Aliquots were accepted if they had a test dose error of $<20 \%$, a recycling ratio within $20 \%$ of unity and recuperation $<5 \%$ of the natural signal, including the uncertainty on each value. Pre-heat plateau tests and dose recovery (measuring a known given dose) with different pre-heat temperatures were used to determine which pre-heat and cut-heat temperature combination was most suitable for each sample. Recuperation was significant $(>5 \%$ of the natural signal) for sample JA2014-07 (Electronic Supplement 1) and an apparent dose resulting from thermal transfer was therefore subtracted from the equivalent dose for that sample (Table 1). The thermal transfer dose for the given pre-heat temperature was determined to $12 \pm 2$ Gy by bleaching aliquots from this sample and measuring them without giving a prior laboratory dose.

The dose rate for each sample was determined by gamma spectrometry at the Nordic Laboratory for Luminescence Dating (Murray et al., 1987) and by estimating the contribution of cosmic radiation according to Prescott \& Hutton (1994). Field and saturated water content (in weight\%) was determined on material from the ends of the sample tubes (Electronic Supplement 1). For the calculation of the final age, the sediments were assumed to have had a water content similar to the field water content for half of the time since deposition, and saturated conditions for half of the time. An exception is sample JA2014-06, for which the natural water content was much lower $(7 \%)$ than in the surrounding samples. The average of the water content in nearby samples $(25 \%$; JA2014-04, JA2014-05, JA2014-07) was therefore used for sample JA2014-06. The mean $\mathrm{D}_{\mathrm{e}}$ was used for age calculations.

\section{Stratigraphy}

The stratigraphy at Skorgenes has previously been described by Larsen \& Ward (1992). The following summary is largely based on their investigations but has been supplemented with findings from Larsen \& Mangerud (1992) and Larsen et al. (1995) as well as with observations made during the sampling for this study (Figs. 2, 3 \& 4). Where not otherwise indicated, all the sediment descriptions below are based on Larsen \& Ward's (1992) original investigations. Their stratigraphic units are still readily identifiable in the exposure and we have noted any observed discrepancy between their observations and ours, but as the focus was on dating the stratigraphy we have not carried out any detailed sedimentological studies to independently verify the observations or interpretations. For detailed sedimentological descriptions we refer to the original articles (Larsen \& Mangerud, 1992; Larsen \& Ward 1992; Larsen et al., 1995). The section and unit names used in this study follow Larsen \& Ward (1992).

\section{Skorgenes unit 1 - proglacial sediments}

Only the upper $c$. $5 \mathrm{~m}$ of the unit was exposed, but according to Larsen \& Ward (1992) the unit is at least $11 \mathrm{~m}$ thick (Figs. $3 \& 5 \mathrm{~A}$ ). In the lower part the sediments consist of alternating beds of primarily sand and gravel but with several beds of clay and silt in between. Upwards, the unit consists of planar parallel-laminated sand with isolated pebbles further up and gravel beds in the uppermost part. Two diamict beds were identified in the lower part (Larsen \& Ward, 1992). The unit was interpreted as proglacial sediments deposited in a subaqueous environment with repeated mass movements and highly fluctuating energy levels (Larsen \& Ward, 1992).

During the fieldwork in 2014, only the upper, sandy part of the unit was exposed and OSL samples JA201412, JA2014-13 and JA2014-14 were all taken in this part. Two samples, el90052 and el89020, were earlier dated with OSL and TL dating in unit 1 during the original investigations at the site (Table 1; Larsen \& Ward, 1992).

\section{Skorgenes unit 2 - diamicton, interpreted as till}

Unit 2 is a crudely stratified diamicton with a silty sand matrix and an average clast size ranging from cobbles to boulders. The contact to underlying sediments is sharp in parts of the section whereas shearing and incorporation of underlying sediments were observed in other parts. Sorted sand and gravel are found in deformed lenses within the diamicton. Fabric measurements showed S-N or SSW-NNE stress directions with a weak to moderate strength in the lower and central part of the unit. Higher up the stress direction shifted to SE-NW but only weak fabric strengths were recorded. Striations were observed on some of the clasts (Larsen \& Ward, 1992). Finegrained clastic dykes originating at the interface between units 1 and 2 have been injected into unit 1 below (Larsen \& Mangerud, 1992).

Larsen \& Ward (1992) interpreted unit 2 as a basal till based on the nature of the lower contact, the clastic dykes originating from this unit, and the presence of striated clasts. For the uppermost 2 metres a proglacial or supraglacial deposition was suggested (Larsen \& Ward, 1992). 

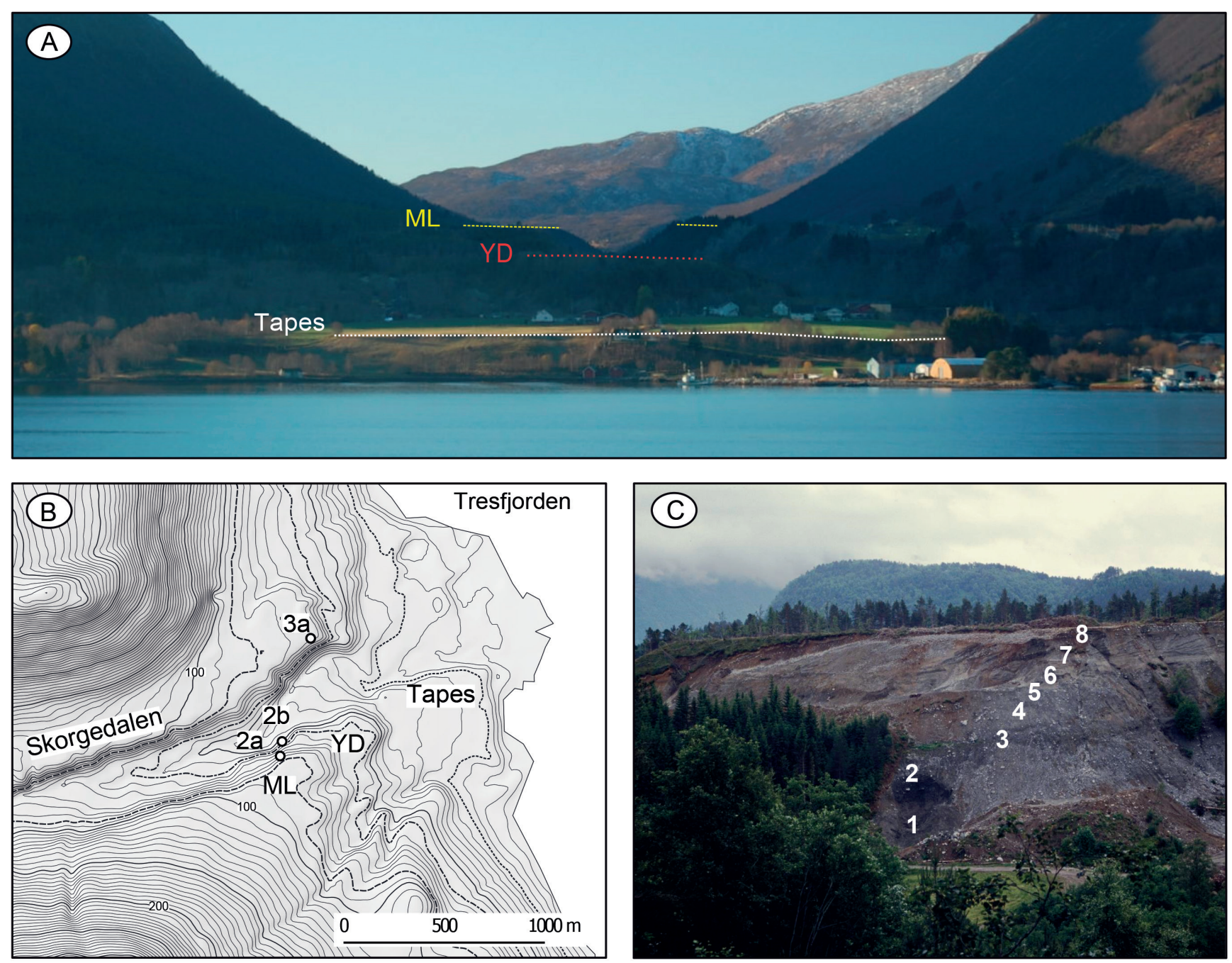

Figure 2. (A) View towards Skorgedalen from the eastern side of Tresfjorden. The marine limit (ML), Younger Dryas (YD) and Tapes terraces are indicated. (B) Detailed map of the study area. The positions of sections $2 A, 2 B$ \& $3 A$ are indicated. Altitude is shown with $5 \mathrm{~m}$ contours. The $20 \mathrm{~m}, 60 \mathrm{~m}$ and $90 \mathrm{~m}$ contours corresponding to the approximate sea level during the formation of the ML, YD and Tapes terraces are indicated with dashed lines. (C) Overview photo over sections $2 \mathrm{~A}$ and $2 \mathrm{~B}$; the approximate positions of units 1-8 are indicated.

\section{Skorgenes units 3 and 4 - bottom- and foreset beds}

Larsen \& Ward (1992) described unit 3 as a coarseningupward sequence starting with laminated or massive clay and silt in the bottom and coarsening into silt and fine sand in the top. Outsized clasts occur throughout the unit but are most abundant in the lower part. Load structures, flames and small-scale convolute bedding were also identified. Larsen et al. (1995) did oedometer tests on four samples from the unit and found them heavily overconsolidated with estimated preconsolidation pressures varying between 12 and $17.5 \mathrm{MPa}$ (best estimate $15 \pm 1 \mathrm{MPa}$ ). Larsen \& Ward (1992) interpret these sediments as bottomsets deposited by rapid sedimentation from suspension in front of a prograding delta.

Unit 4 is an up to $11.5 \mathrm{~m}$-thick unit characterised by a succession of $5-50 \mathrm{~cm}$-thick beds of moderately to well sorted sediments ranging from fine sand to cobbly gravel. The dip of the beds increases up to approximately $25^{\circ}$ in the upper part. A general coarsening-upward trend is visible in the unit. Larsen \& Ward (1992) interpret these beds as delta foreset beds. Units 3 and 4 would thus consist of the bottomsets (unit 3; Fig. 5B) and foresets (unit 4; Fig. 5C) of a prograding delta, an interpretation we support. As no topset beds were identified, deposition could also have been in a subaqueous fan. The top of unit 4 is situated at $84 \mathrm{~m}$ a.s.l., which gives a minimum elevation of the sea level during deposition, assuming deposition in the sea.

Samples JA2014-04, JA2014-05, JA2014-06 and JA201407 were all taken in the foreset beds of unit 4 . Sample el 90075 was taken in the same section during the original investigations (Larsen \& Ward, 1992). 

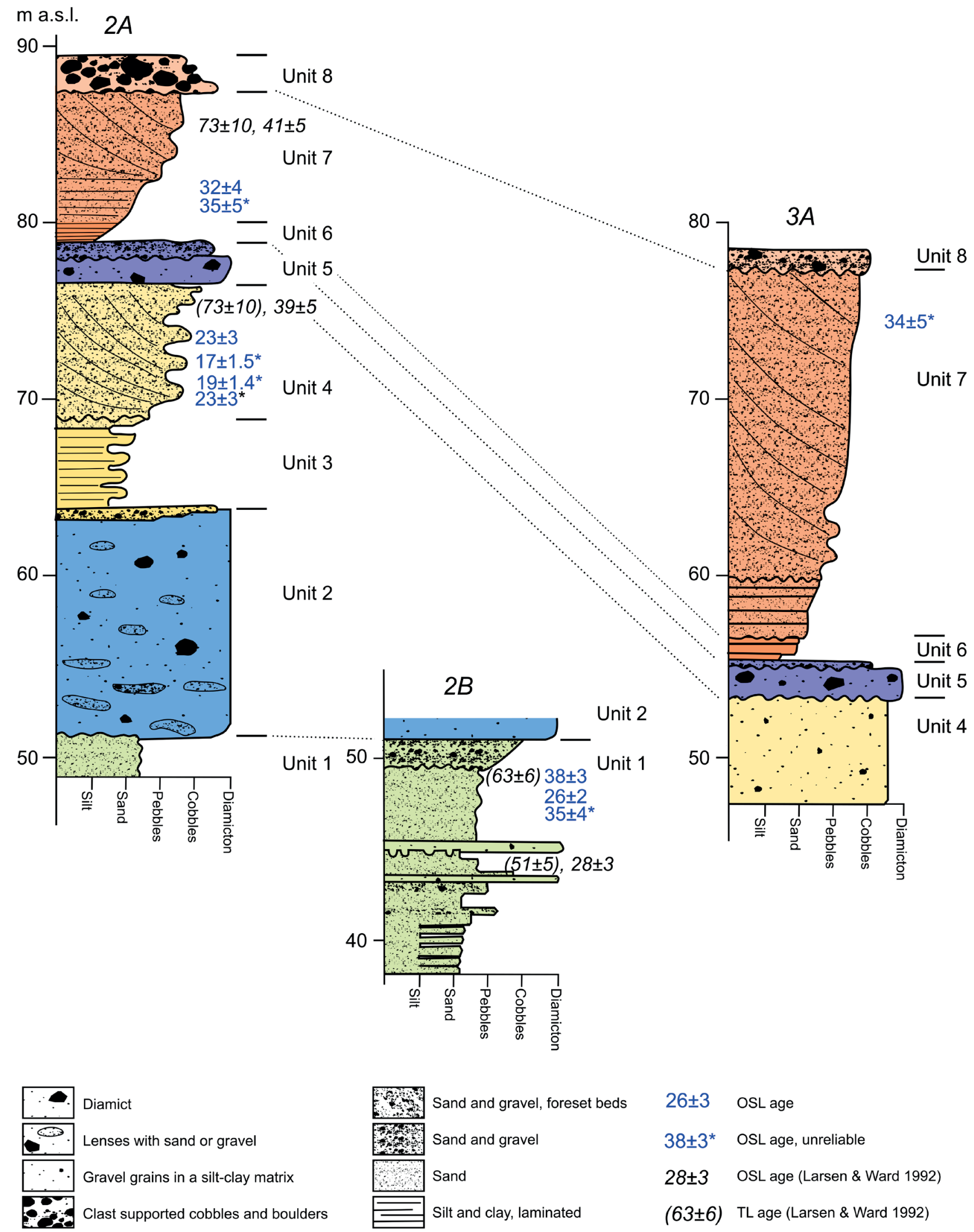

Figure 3. Sediment logs for sections $2 A, 2 B$ \& $3 A$ redrawn from Larsen \& Ward (1992). The units are highlighted with different colours. The new ages from this study are indicated in blue. 


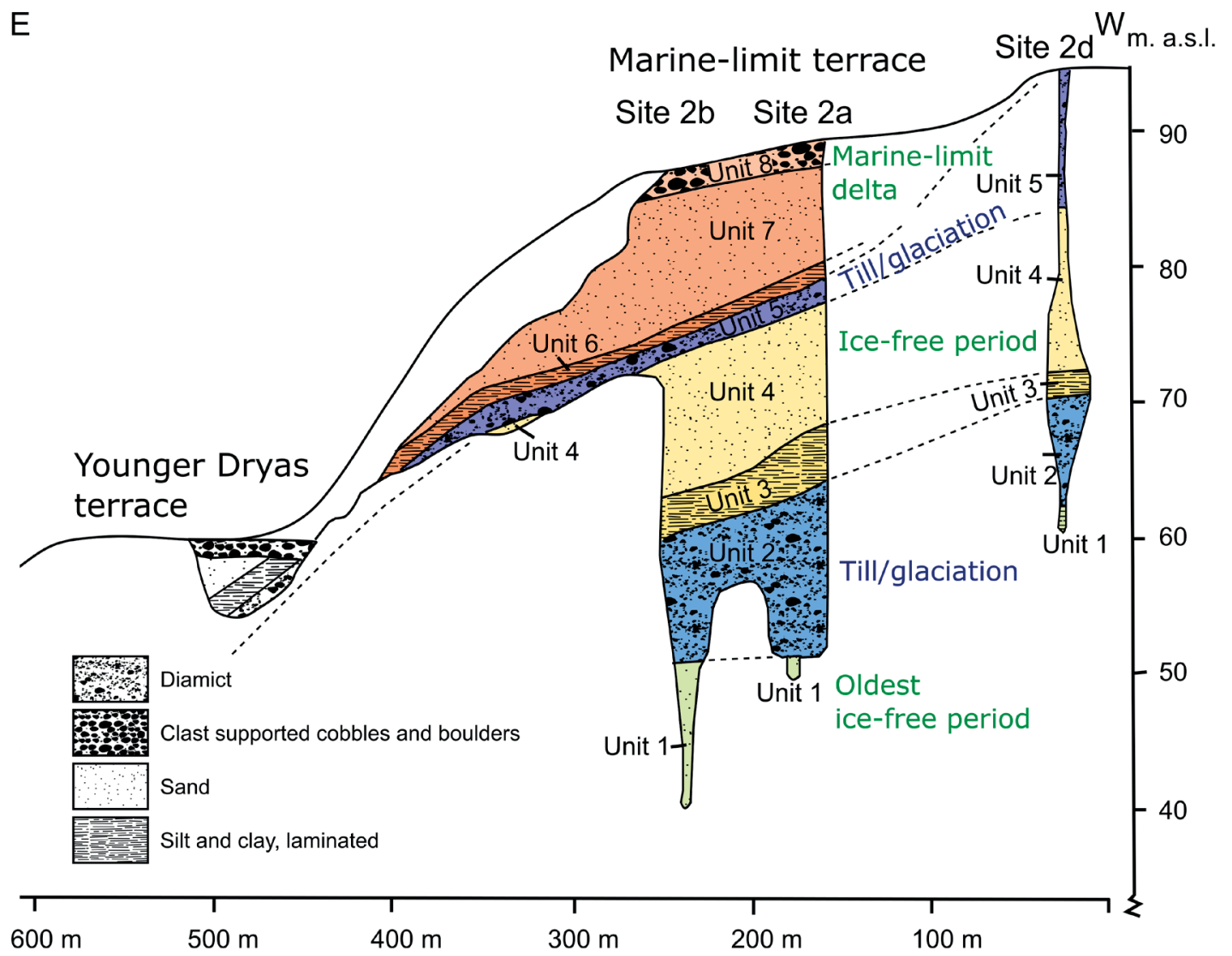

Figure 4. Profile drawing of the sections on the south side of the Skorgedalen valley. Redrawn from Larsen \& Ward (1992).

\section{Skorgenes unit 5 -diamicton, interpreted as till}

Unit 5 is a comparatively thin diamicton, in most places less than two metres thick, which overlies unit 4 with a sharp and likely erosional lower boundary (Larsen \& Ward, 1992). The sediments are generally massive with a silty sandy matrix but in some places a weak stratification was visible. Gravel lenses were also observed in the unit. Five measurements of clast fabric were made, four of them indicated preferred directions ranging from $\mathrm{S}-\mathrm{N}$ to SW-NE. This unit was interpreted as a proximal glacial diamicton consisting mostly of basal till (Larsen \& Ward, 1992). Based on the overconsolidation of the underlying unit 3, Larsen et al. (1995) estimated an ice with a thickness of around $1100 \mathrm{~m}$, which likely implies an ice sheet extending to the shelf break or thereabout.

\section{Skorgenes units 6,7 and 8, delta deposits}

Unit 6 is characterised by laminated sediments, starting with alternating fine sand and clayey silt in the lower part and gradually coarsening upward. The lower boundary to unit 5 is conformable. Outsized clasts were found throughout the unit but are most abundant in the lower part. Larsen \& Ward (1992) suggested that unit 6 was deposited in a glaciomarine environment in front of a prograding delta, similar to the depositional environment suggested for unit 3. Two oedometer samples from unit 6 gave preconsolidation values from 2 to $2.6 \mathrm{MPa}$. This is somewhat higher than can be explained by the pressure of the overlying sediments alone and the overconsolidation was attributed to cycles of freezing and thawing (Larsen et al., 1995).

A gradual transition was observed between unit 6 and the alternating beds of sand and gravel that form unit 7. The dip of the beds in unit 7 increases upward up to a $25^{\circ}-30^{\circ}$ dip eastward, consistent with a flow direction out of Skorgedalen. Larsen \& Ward (1992) interpreted this unit as delta foreset beds.

The uppermost unit, unit 8 , overlies unit 7 with an erosional lower boundary. The unit is coarse with cobbles and boulders in a matrix ranging from coarse sand to pebbles. A weak horizontal stratification is visible.

Larsen \& Ward (1992) interpret units 6, 7 and 8 as the bottomsets (unit 6; Fig. 5D), foresets (unit 7; Fig. 5E) and topsets (unit 8; Fig. 5F) of a prograding delta. OSL sample JA2014-09 was taken in the transition between unit 6 and 7 and samples JA2014-10, JA2014-11, JA201416 and JA2014-8 were taken in unit 7. Sample el90076 was taken in unit 7 during the original study (Larsen \& Ward, 1992). 

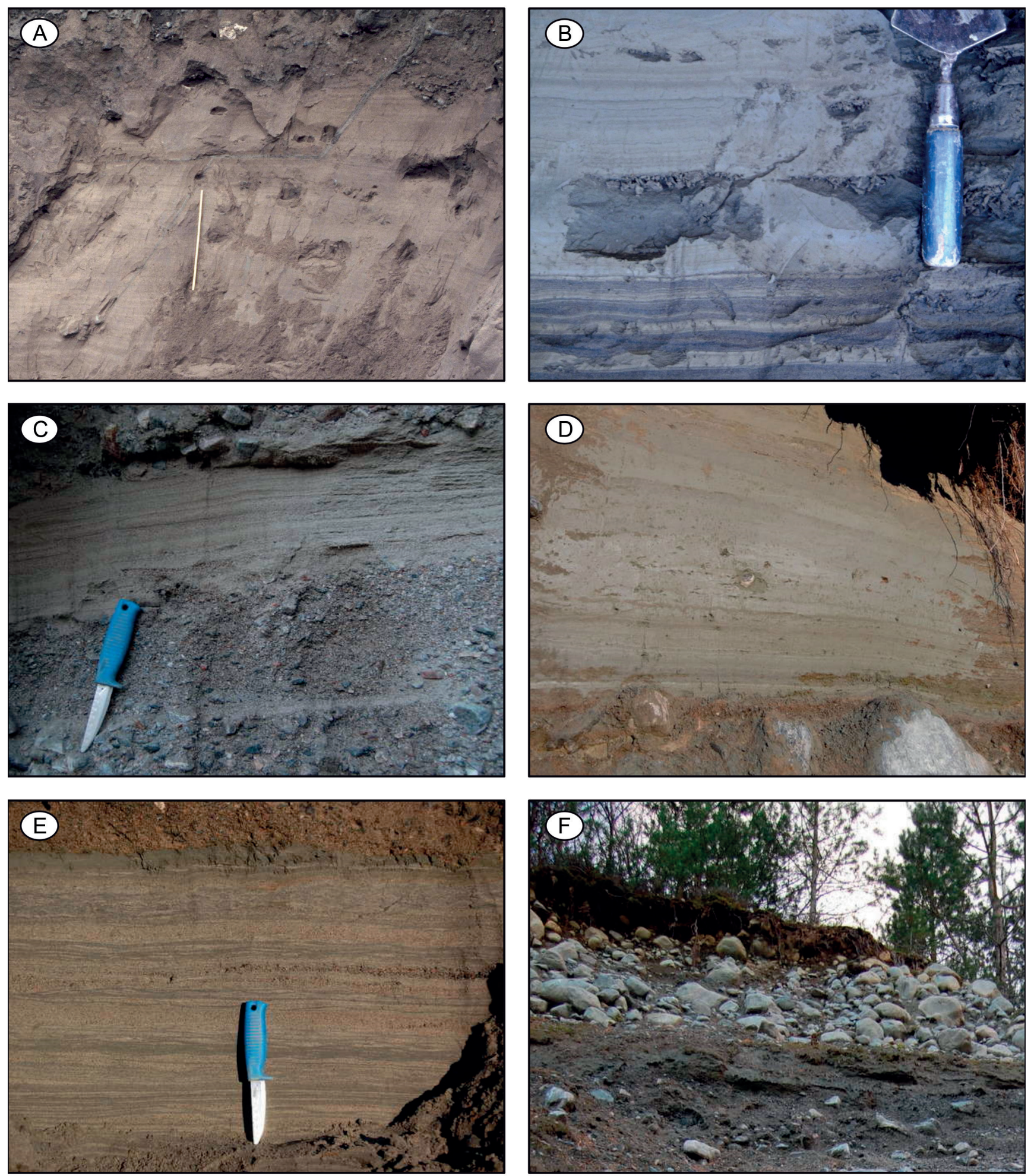

Figure 5. Sediment photographs from Skorgenes. (A) Proglacial sediments, unit 1, section 2B. (B) Bottomsets, unit 3, section 2B, (photograph Brent Ward). (C) Foreset beds, unit 4, section 2A. (D) Bottomsets, unit 6, section 3A. (E) Foreset beds, unit 7, section 3A. (F) Topset beds, unit 8, section $2 A$.

We note that the base of unit 8 is situated about $11 \mathrm{~m}$ lower at site $3 \mathrm{~A}$ compared to sites $2 \mathrm{~A}$ and $2 \mathrm{~B}$ on the other side of the valley. As unit 8 consists of topset beds, the base of which should broadly reflect the relative sea level at the time of deposition, such a large difference in altitude is surprising. The sites are close to each other and we find no local topographic control that could explain the discrepancy. We still find the correlation between the sites suggested by Larsen \& Ward (1992) to be the most reasonable and suggest that this altitude difference probably indicates that the topset beds at $3 \mathrm{~A}$ were formed during the emergence of the area. A comparison with the regional relative sea-level curves reconstructed by Svendsen \& Mangerud (1987) suggests that the observed 
difference in altitude would amount to an age difference of roughly 600 years. None of the samples taken from site 3A (JA2014-16 and JA2014-18) is critical for the suggested chronology.

\section{Evaluation of the stratigraphy}

The importance of the Skorgenes site is largely dependent on its regionally unique stratigraphy in which sediments deposited during three ice-free intervals (units 1, 3-4 \& 6-8) interrupted by two glacial advances (units $2 \& 5$ ) are preserved in the same section (Figs. $3 \& 4$ ). From a chronostratigraphic perspective it is, however, critical to determine whether the two diamict units (units 2 \& 5) represent significant glacial advances over the area or if they could be explained by local events.

For unit 2 the assumption of a large-scale ice advance appears well justified. The unit is interpreted as a basal till and the depositional environment shifts notably between the underlying unit 1 and unit 3 above. Unit 3 appears to have been deposited below the wave-base which is easiest to explain with isostatic depression. In addition, three fabric measurements ranging from $\mathrm{S}-\mathrm{N}$ to SSW-NNE fit poorly with a local ice advance in the E-W-trending Skorgedalen.

For unit 5 the interpretation is less straightforward. This unit was interpreted as a proximal glacial diamicton by
Larsen \& Ward (1992) and could have been deposited during a deglaciation. The diamict in itself is thus not sufficient evidence of a significant ice advance over the area. However, the high preconsolidation values of the underlying unit 3 strongly suggest that the site was overridden by a thick ice at some point between the deposition of unit 3 and unit 5 (Larsen et al., 1995).

\section{OSL results}

All twelve samples have dim OSL signals with a weak fast component, and are characterised by large sensitivity change throughout the SAR protocol (Fig. 6). Only one sample, JA2014-13, passed the standard acceptance criteria for OSL dating (Murray \& Wintle, 2000). Three more (JA2014-07, JA2014-11 and JA2014-14) passed if error margins on, e.g., dose recovery ratios were considered (Table 1; Electronic Supplement 2). These four samples are considered acceptable, although only a few measurements could be done on sample JA2014-11 due to the small amount of material of the right grain size. Two samples, JA2014-09 and JA2014-16, failed even with the most generous criteria and were therefore discarded from further measurements. These two samples are included in Table 1 but not further discussed in the text. The remaining samples are considered unreliable, particularly due to very poor dose recovery ratios, and the results must be interpreted with caution (Table 1).

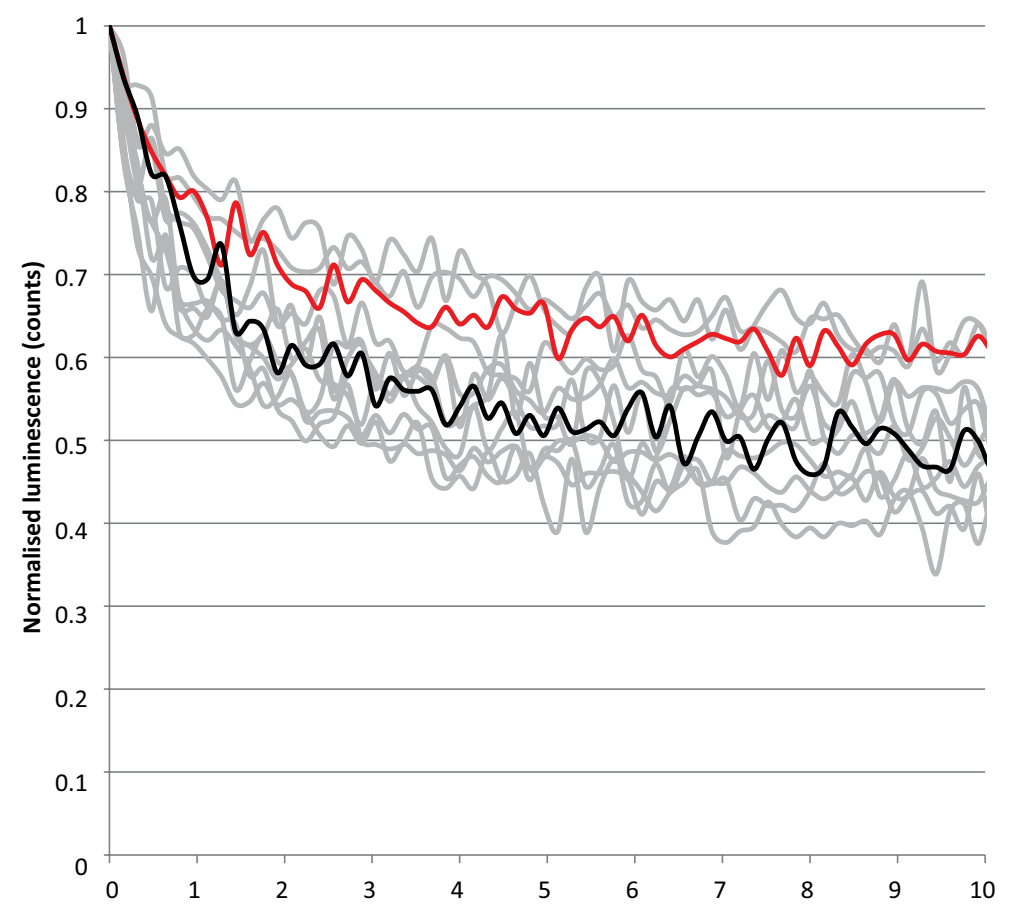

Figure 6. Natural decay curves for all Skorgenes samples. JA2014-13 (good) in black and JA2014-05 (unreliable) in red have been highlighted as examples. Only the first ten seconds of stimulation are shown. 


\section{Chronology}

The new OSL ages from Skorgenes range from $17 \pm 1.5$ $\mathrm{ka}$ (JA2014-06) to $38 \pm 3 \mathrm{ka}$ (JA2014-12; Table 1). The very large uncertainties for the OSL ages mean that great caution is necessary when interpreting the results. The large uncertainties are mainly due to the nature of the quartz luminescence signals: the weak fast component and the large sensitivity changes. This, in turn, is likely due to the mostly metamorphic origin of the quartz and its relatively short transport history as has been shown elsewhere in Scandinavia (Alexanderson \& Murray, 2012). Additional uncertainty comes from the difficulty in correctly estimating the average environmental dose rate through time as it depends for example on the sediment water content, which is likely to have changed with changing sea level and proximity to ice sheets. However, even assuming fully water saturated sediments for the entire time since deposition would only age the samples by on average $1.3 \mathrm{ka}$ (maximum $3.2 \mathrm{ka}$ ) which would only have a minor influence on the chronology.

All ages fall within the Middle and Late Weichselian, as expected from the setting, and some clustering within the individual units can be observed (Table 1). We therefore believe that the ages do reflect the sedimentation ages, although with a larger than normal scatter. As a conservative estimate, we suggest that the true sedimentation age of a unit can be expected to fall within two standard deviations of at least one technically good or acceptable OSL age from that unit (that is JA2014-07, JA2014-11, JA2014-13 and JA2014-14) or within two standard deviations of two of the unreliable ages. The unreliable ages include the remaining OSL samples, including the ones from Larsen \& Ward (1992), but exclude the ages identified as not usable based on their technical properties and the feldspar ages from Larsen \& Ward (1992). By requiring that an unreliable sample must be supported by another sample to be used to define the age range, we somewhat arbitrarily attempt to compensate for the additional uncertainties with these samples. Considering the very poor dose recovery ratios of the samples identified as unreliable it can be argued that these ages should also be excluded from the chronology. However, as including these ages result in wider age ranges than what we would get if we included only the technically acceptable ages (which would give more precise ranges but based on very few samples) we consider this a more conservative approach. Considering that all the dated units were deposited in an ice-proximal position, incomplete bleaching is a possibility for all the samples (e.g., Fuchs \& Owen, 2008; Alexanderson \& Murray, 2012). It is thus possible that some or all of the ages should be considered maximum ages for the deposition. In that case the youngest age from each unit could be considered the most reliable, but due to the technical difficulties of these samples we are hesitant to make that assumption. By including all the usable samples we aim to identify the widest age ranges that could be consistent with our data and thereby to include the full uncertainty in our interpretations. With these assumptions the probable age range for unit 1 is $21-42$ ka, between 17 and 30 ka for unit 4 and 24 to $44 \mathrm{ka}$ for unit 7 (Fig. 7).

Taken on their own, these wide age ranges are hardly useful, especially considering that the actual periods of sedimentation are likely to be short. However, the sediment stratigraphy provides further constraints. The uppermost three units, units $6-8$, form a complete and undisturbed glaciomarine delta. It is not overlain by any diamicton and the bottom of the topset bed fits with the estimated Marine Limit in the area. Larsen \& Ward (1992) concluded that these units were deposited when the Late Weichselian ice sheet finally retreated from the area, which is approximately $15 \mathrm{ka}$ (Hughes et al., 2016). Based on the stratigraphy at the site, we agree with this assessment and conclude that our OSL ages from the unit appear to overestimate the true age by in the order of 13-25 ka. Incomplete bleaching during deposition has previously been identified in sediments deposited in similar settings (Fuchs \& Owen, 2008; Alexanderson \& Murray, 2012) and we suggest that this may have caused the old ages.

Units 3 and 4 are separated from the upper delta succession by a glacial diamict. The overconsolidation observed in unit 3 indicates a substantial ice cover (Larsen et al., 1995) and units 3 and 4 are thus noticeably separated in time from units 6-8. The OSL ages from unit 4 are comparatively well clustered with a probable age range between 17 and $30 \mathrm{ka}$. We therefore suggest that units 3 and 4 were deposited during a Late Weichselian ice retreat predating the final deglaciation.

Unit 1 is separated from units 3 and 4 by a $10-12 \mathrm{~m}$-thick basal till. The OSL ages from unit 1 are more scattered than in unit 4 and the suggested probable sedimentation age ranges from 21 to $42 \mathrm{ka}$, indicating that the unit was deposited during a Middle or Late Weichselian interstadial.

\section{Implications}

The wide uncertainties on the sedimentation ages of our units make independent correlations to specific interstadials unrealistic. Instead, we compare the age ranges for our ice-free periods with periods of ice-free conditions identified or suggested from other sites in the region to identify possible correlations (Fig. 7).

The general glaciation history in the region around Skorgenes during Marine Isotope Stage 3 is constrained by well-dated cave deposits in the Skjonghelleren and 

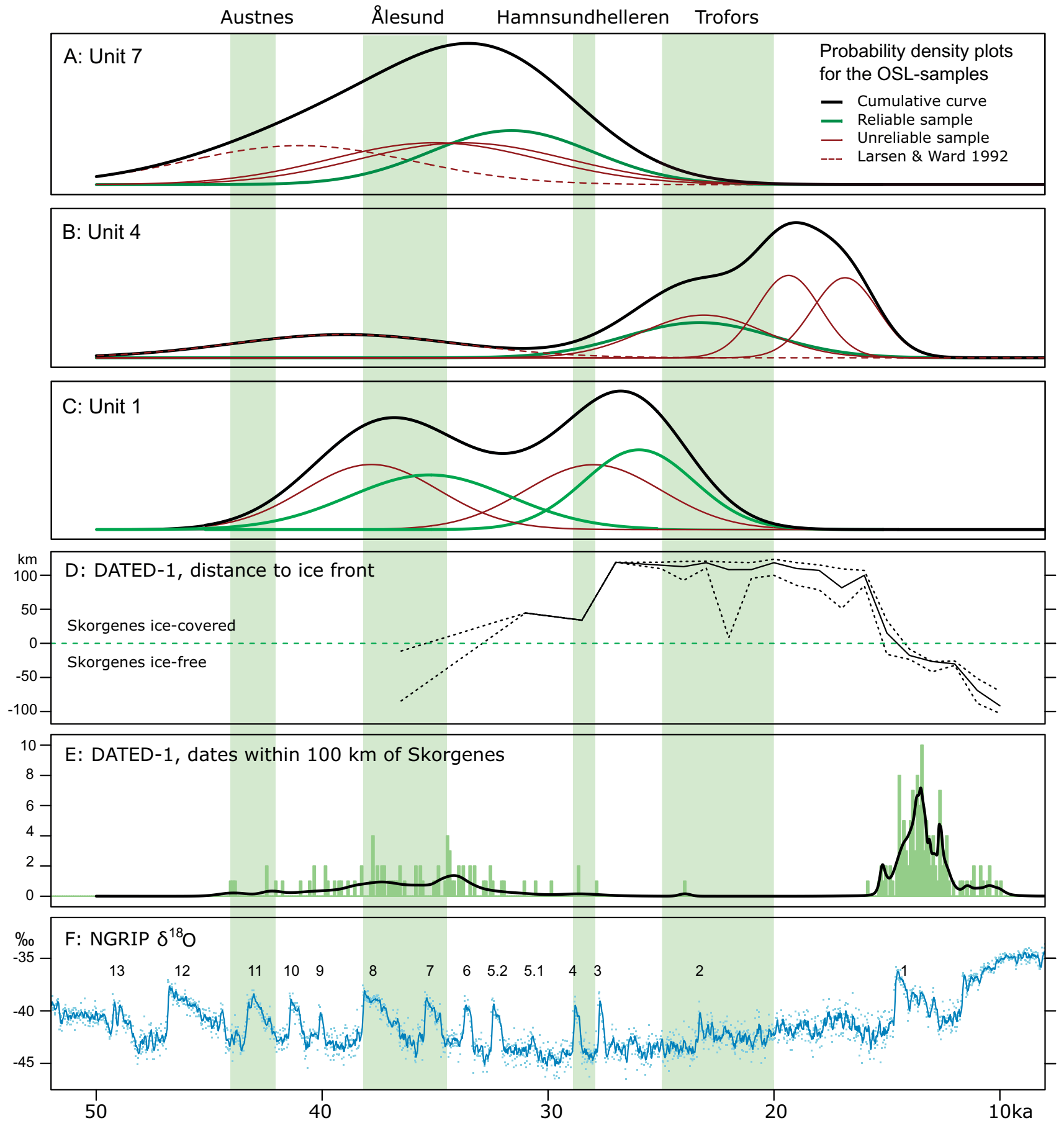

Figure 7. Overview of the OSL ages from Skorgenes compared to the regional glaciation reconstruction from DATED-1 (Hughes et al., 2016) and the NGRIP ice core. The Austenes, Alesund, Hamnsundhelleren and Trofors interstadials are indicated in green. Note that only the end of the Austenes interstadial is dated and that although the Trofors interstadial has been dated to sometime between 20 and $25 \mathrm{ka}$ the length of this interstadial is unknown (Olsen et al., 2001; Johnsen et al., 2012). (A-C). The OSL ages from each unit have been plotted. The reliable samples (classified as good or OK) are indicated in green, unreliable samples in red and OSL ages from Larsen \& Ward (1992) as dashed lines. A cumulative curve for all the samples in each unit is indicated in black. (D) Distance from Skorgenes to the ice-front position suggested by Hughes et al. (2016). Minimum and maximum estimates are indicated with dashed lines. Negative values indicate periods when Skorgenes would be ice free according to the DATED-1 reconstruction. (E) Histogram of the mean ages for all ages within $100 \mathrm{~km}$ from Skorgenes in the DATED-1 database (green) and a normal kernel density estimate (black) of the same ages including their uncertainties (Hughes et al., 2016). (F) NGRIP $\delta^{18} \mathrm{O}$ data (GICC05 age scale, North Greenland Ice Core Project Members, 2004; Svensson et al., 2008). The Greenland Interstadials are indicated. 
Hamnsundhelleren caves west of Skorgenes (Larsen et al., 1987, Valen et al., 1996; Mangerud et al., 2010) which indicate the glacial advances and retreats at the outer coast. The oldest interstadial identified in these caves, the Austnes interstadial, ended at around $42 \mathrm{ka}$ (Mangerud et al., 2010) and we therefore consider a correlation with unit 1 to be possible but unlikely. This interstadial was followed by a glacial advance which must also have covered Skorgenes.

A second interstadial, the Ålesund interstadial, has been dated to 34.5-38.2 cal. ka BP based on a large number of radiocarbon dates from the Skjonghelleren and Hamnsundhelleren caves (Mangerud et al., 2010). The age fits well within the age range identified for unit 1 at Skorgenes and we therefore suggest that the Ålesund interstadial is a reasonable correlation for unit 1.

Possible ice-free stages during the Late Weichselian are substantially less well constrained than the previously mentioned interstadials. However, two radiocarbon ages from the Hamnsundhelleren cave (Valen et al., 1996; Mangerud et al., 2010) give some support for an ice retreat from the outer coast at around 28-29 cal. ka BP. Also, Olsen et al. (2001) have suggested an ice retreat around this time $(\sim 29-32 \mathrm{ka})$, although the latter dataset has large uncertainties. A retreat at this time, assuming that the ice front retreated as far east as Skorgenes, would be another plausible correlation for unit 1 . A correlation with unit 4 , with a probable age range of $17-30 \mathrm{ka}$, is also reasonable.

An even younger period of ice-free conditions in the region, the Trofors interstadial, has been suggested to have occurred at some point between 20 and $25 \mathrm{ka}$ based on bulk radiocarbon ages (Olsen et al., 2001) and OSL ages (Johnsen et al., 2012). This time range overlaps with the probable age ranges defined for both unit 1 and unit 4 . As the stratigraphy at Skorgenes indicates a substantial glacial advance between the deposition of units 1 and 4, we consider it unlikely that these units were deposited during the same regional ice retreat. We therefore find it unlikely that unit 1 would have been deposited during a possible Trofors interstadial. However, a correlation between such an interstadial and unit 4 would be consistent with our OSL ages. Although the sediments in unit 4 cannot be conclusively tied to a specific interstadial, our new dates indicate they were deposited during the Late Weichselian and that the area thus became ice free at least once between the Ålesund interstadial and the final deglaciation.

The area was finally deglaciated at around $15 \mathrm{ka}$ (Hughes et al., 2016) and a marine limit delta started to build up at the outlet of the Skorgedalen valley (unit 6-8).

\section{Conclusions}

At Skorgenes in western Norway, sediments from three ice-free periods have been identified in the same section. The site is therefore a key site for the stratigraphy in the region but poor age control has limited its usefulness. In this study, we present ten new OSL dates which constrain the timing of these periods. The samples had poor OSL properties but the ages are still a substantial improvement on the existing chronology.

\section{Three ice-free periods were identified at Skorgenes:}

- The oldest unit (unit 1) consists of sediments deposited in a proglacial subaqueous setting. OSL ages from this unit indicate deposition at some point between 21 and $42 \mathrm{ka}$, indicating a Middle or Late Weichselian retreat most likely correlated with either the Ålesund interstadial (34.5-38.2 ka) or a possible Hamnsund interstadial at around 28-29 ka. This stage was followed by a glacial advance depositing a basal till (unit 2).

- As the ice-sheet retreated again, a delta or a subaqueous fan started to form at Skorgenes. OSL ages from the foreset beds (unit 4) suggest that it was deposited at some point between 17 and $30 \mathrm{ka}$ implying that the ice-front retreated east of Skorgenes at least once during the Late Weichselian. Such a retreat could fit with either a Hamnsund interstadial or a younger Trofors interstadial (suggested age somewhere between 20 and $25 \mathrm{ka}$ ) but neither of these proposed interstadials has previously been conclusively identified around Skorgenes.

- Skorgenes was once more glaciated during the LGM. As the ice-front retreated a marine limit delta (units 6-8) was formed. OSL ages from this unit are all more than $30 \mathrm{ka}$ indicating an incomplete bleaching of the sediments but the stratigraphic position ties it to the final deglaciation.

Acknowledgements. Sample preparation was done by Sara Florén. Vicki Hansen and Eun-Young Yoo carried out the gamma spectrometry. Jan Mangerud and Sven Lukas provided helpful and constructive reviews on the manuscript. An anonymous reviewer provided constructive comments on an earlier version of the manuscript. 


\section{References}

Alexanderson, H. 2007: Residual OSL signals from modern Greenlandic river sediments. Geochronometria 26, 1-9. https://doi.org/10.2478/v10003-007-0001-6.

Alexanderson, H. \& Murray, A.S. 2012: Problems and potential of OSL dating Weichselian and Holocene sediments in Sweden. Quaternary Science Reviews 44, 37-50. https://doi.org/10.1016/j.quascirev.2009.09.020.

Alexanderson, H., Johnsen, H. \& Murray, A.S. 2010: Re-dating the Pilgrimstad Interstadial with OSL: a warmer climate and a smaller ice sheet during the Swedish Middle Weichselian (MIS 3)? Boreas 39, 367-376. https://doi.org/10.1111/j.1502-3885.2009.00130.x.

Duller, G.A.T. 2003: Distinguishing quartz and feldspar in single grain luminescence measurements. Radiation Measurements 37, 161-165. https://doi.org/10.1016/S1350-4487(02)00170-1.

Fuchs, M. \& Owen, L.A. 2008: Luminescence dating of glacial and associated sediments: review, recommendations and future directions. Boreas 37, 636-659. https://doi.org/10.1111/j.1502-3885.2008.00052.x.

Hättestrand, M. \& Robertsson, A.M. 2010: Weichselian interstadials at Riipiharju, northern Sweden - interpretation of vegetation and climate from fossil and modern pollen records. Boreas 39, 296-311. https://doi.org/10.1111/j.1502-3885.2009.00129.x.

Helmens, K.F., Risberg, J., Jansson, K.N., Weckström, J., Berntsson, A., Kaislahti-Tillman, P., Johansson, P.W. \& Wastegård, S. 2009: Early MIS 3 glacial lake evolution, ice-marginal retreat pattern and climate at Sokli (northeastern Fennoscandia). Quaternary Science Reviews 28, 1880-1894. https://doi.org/10.1016/j.quascirev.2009.03.001.

Hughes, A.L.C., Gyllencreutz, R., Lohne, Ø.S., Mangerud, J. \& Svendsen, J.I. 2016: The last Eurasian Ice Sheets - a chronological database and time-slice reconstruction, DATED-1. Boreas 45. 1-45. https://doi.org/10.1111/bor.12142.

Johnsen, T.F., Olsen, L. \& Murray, A. 2012: OSL ages in central Norway support a MIS 2 interstadial (25-20 ka) and a dynamic Scandinavian ice sheet. Quaternary Science Reviews 44, 96-111. https://doi.org/10.1016/j.quascirev.2010.10.007.

Larsen, E. \& Mangerud, J. 1992: Subglacially formed clastic dikes. Geological Survey of Sweden, Series Ca 81, 163-170.

Larsen, E. \& Ward, B. 1992: Sedimentology and stratigraphy of two glacial-deglacial sequences at Skorgenes, western Norway. Norwegian Journal of Geology 72, 357-368.

Larsen, E., Gulliksen, S., Lauritzen, S.E., Lie, R., Løvlie, R. \& Mangerud, J. 1987: Cave stratigraphy in western Norway; multiple Weichselian glaciations and interstadial vertebrate fauna. Boreas 16, 267-292. https://doi.org/10.1111/j.1502-3885.1987.tb00096.x.

Larsen, E., Sandven, R., Heyerdahl, H. \& Hernes, S. 1995: Glacial geological implications of preconsolidation values in sub-till sediments at Skorgenes, western Norway. Boreas 24, 37-46. https://doi.org/10.1111/j.1502-3885.1995.tb00626.x.

Larsen, E., Fredin, O., Lyså, A., Amantov, A., Fjeldskaar, W. \& Ottesen, D. 2016: Causes of time-transgressive glacial maxima positions of the last Scandinavian Ice Sheet. Norwegian Journal of Geology 96, 1-12. https://doi.org/10.17850/njg96-2-06.

Mangerud, J., Gulliksen, S. \& Larsen, E. 2010: ${ }^{14} \mathrm{C}$-dated fluctuations of the western flank of the Scandinavian Ice Sheet 45-25 kyr BP compared with Bølling-Younger Dryas fluctuations and Dansgaard-Oeshger events in Greenland. Boreas 39, 328-342. https://doi.org/10.1111/j.1502-3885.2009.00127.x.

Möller, P., Anjar, J. \& Murray, A.S. 2013: An OSL-dated sediment sequence at Idre, west-central Sweden, indicates ice-free conditions in MIS 3. Boreas 42, 25-42.

https://doi.org/10.1111/j.1502-3885.2012.00284.x.
Murray, A.S., Marten, R., Johnson, A. \& Martin, P. 1987: Analysis for naturally occurring radionuclides at environmental concentrations by gamma spectrometry. Journal of Radioanalytical and Nuclear Chemistry Articles 115, 263-288.

https://doi.org/10.1007/BF02037443.

Murray, A.S. \& Wintle, A.G. 2000: Luminescence dating of quartz using an improved single-aliquot regenerative dose protocol. Radiation Measurements 32, 57-73. https://doi.org/10.1016/S1350-4487(99)00253-X.

Murray, A.S. \& Wintle, A.G. 2003: The single aliquot regenerative dose protocol: potential for improvements in reliability. Radiation Measurements 37, 377-381. https://doi.org/10.1016/S1350-4487(03)00053-2.

North Greenland Ice Core Project Members 2004: High-resolution record of Northern Hemisphere climate extending into the last interglacial period. Nature 431, 147-151. https://doi.org/10.1038/nature02805.

Olsen, L., Van der Borg, K., Bergstrøm, B., Sveian, H., Lauritzen, A.E. \& Hansen, G. 2001: AMS radiocarbon dating of glacigenic sediments with low organic carbon content - an important tool for reconstructing the history of glacial variations in Norway. Norwegian Journal of Geology 81, 59-92.

Prescott, J.R. \& Hutton, J.T. 1994: Cosmic ray contributions to dose rates for luminescence and ESR dating: large depths and long-term time variations. Radiation Measurements 23, 497-500. https://doi.org/10.1016/1350-4487(94)90086-8.

Svendsen, J.I. \& Mangerud, J. 1987: Late Weichselian and Holocene sea-level history for a cross-section of western Norway. Journal of Quaternary Science 2, 113-132. https://doi.org/10.1002/jqs.3390020205.

Svensson, A., Andersen, K.K., Bigler, M., Clausen, H.B., Dahl-Jensen, D., Davies, S.M., Johnsen, S.J., Muscheler, R., Parrenin, F., Rasmussen, S.O., Rothlisberger, R., Seierstad, I., Steffensen, J.P. \& Vinther, B.M. 2008: A 60,000 year Greenland stratigraphic ice core chronology. Climate of the Past 4, 47-57. https://doi.org/10.5194/cp-4-47-2008.

Truelsen, J.L. \& Wallinga, J., 2003: Zeroing of the OSL signal as a function of grain size: investigating bleaching and thermal transfer for a young fluvial sample. Geochronometria 22, 1-8.

Valen, V., Mangerud, J., Larsen, E. \& Hufthammer, A.K. 1996: Sedimentology and stratigraphy in the cave Hamnsundhelleren, western Norway. Journal of Quaternary Science 11, 185-201. https://doi.org/10.1002/(SICI)1099-1417(199605/06)11:3< 185::AID-JQS247>3.0.CO;2-Y.

Wohlfarth, B., Alexanderson, H., Ampel, L., Bennike, O., Engels, S., Johnsen, T., Lundqvist, J. \& Reimer, P. 2011: Pilgrimstad revisited multi-proxy reconstructions of Early/Middle Weichselian climate and environment at a key site in central Sweden. Boreas 40, 211230. https://doi.org/10.1111/j.1502-3885.2010.00192.x. 